\title{
Designing and Implementing Utility Line Arboreta
}

\author{
Bonnie L. Appleton
}

\begin{abstract}
In the United States, a significant conflict exists between overhead utility lines and inappropriately tall trees planted in or near line easements. A major goal of Virginia, U.S.'s Municipal Tree Restoration Project is the establishment of utility line arboreta in multiple state locations as a way to evaluate, showcase, and promote trees compatible with overhead utility lines. Three different utility line arboreta models have been developed that can be replicated anywhere internationally to deal with this important infrastructure conflict. A stepwise list of considerations and potential funding sources for developing utility line arboreta is provided, as well as a comparison of the advantages and disadvantages of the three described utility line arboreta models.
\end{abstract}

Key Words. Electrical power; line clearance; Municipal Tree Restoration Project (MTRP); power outage; species selection; utility-compatible trees; utility easements; utility pruning; utility right-of-way management.

Although most people take for granted our generally uninterrupted delivery of electrical power, in many areas of the United States there is a major and potentially disastrous conflict between overhead utility lines and inappropriately tall trees planted in or near line easements (Appleton 2004). Trees can cause power outages by direct contact with lines, as they or their branches fall on lines or damage electrical equipment or support structures, or by electrical arcing between tree parts and nearby high-voltage conductors (U.S.-Canada Power System Outage Task Force 2004).

Two recent occurrences underscore this tree-electric line conflict. On 14 August 2003, an electric power blackout occurred that affected large portions of Ontario, Canada, and the midwestern and northeastern sections of the United States. In some parts of the United States, power was not restored for 4 days. A final report on the blackout stated:

\section{From 15:05:41 EDT to 15:41:35 EDT, three 345-kV lines failed with power flows at or below each trans- mission line's emergency rating. These line trips were not random. Rather, each was the result of a contact between a line and a tree that had grown so tall that, over a period of years, it encroached into the required clearance height for the line...Each of these three lines tripped not because of excessive sag due to overloading or high conductor temperature, but because it hit an overgrown, untrimmed tree (U.S.-Canada Power Sys- tem Outage Task Force 2004).}

Shortly thereafter, on 18 September 2003, Hurricane Isabel caused major electric power outages along the mid-Atlantic coast. This power outage affected more than 6.5 million customers at the storm's peak, five times the number of outages caused by Hurricane Andrew; until the 2005 season, it was the most costly of all hurricanes (Department of Energy 2003). According to Dominion Virginia Power, one of the nation's largest producers of energy, Hurricane Isabel was the worst storm in the company's 100-year history (Dominion Virginia Power 2003). In southeastern Virginia 94\% of customers lost electrical service (which in some cases took 2 weeks to be restored); $84 \%$ of customers in northeastern North Carolina lost power. Falling limbs and whole trees torn from sodden ground were in great part responsible for 62 downed transmission lines (1,600 miles of high-voltage lines), 1,150 disrupted primary distribution circuits, 2,311 broken utility poles, 3,899 snapped cross arms, and 7,363 spans of downed power lines.

Every year, North American utilities spend an estimated \$2 to $\$ 10$ billion for vegetation management along utility lines (Guggenmoos 2003). Vegetation management ranges from line-clearance pruning and whole tree and tree debris removal along all lines to the application of herbicides to kill or retard growth of any vegetation type in transmission line rights of way. Preventive maintenance generally involves conducting these activities on regular, predetermined cycles depending on line location, vegetation (including trees) height and growth rate, and local regulatory reliability and clearance requirements. Corrective maintenance is performed on an asneeded basis (often related to wind and ice storms, hurricanes, tree-related outages, and so forth).

Although line clearance may result in trees deemed aesthetically unacceptable, in the United States not only has legal precedent established that utilities have the right to prune and remove trees that interfere with necessary and reasonable utility operations (Merullo and Valentine 1992), but utilities are legally required to do so (ANSI 1997). Although numerous options, including burying utility lines and applying tree growth regulators, exist to deal with this conflict, one 
of the most practical solutions is the selection and planting of trees with mature heights compatible with overhead electric lines. This solution can improve the appearance of the landscape, prevent safety hazards, improve electric service reliability, and reduce line-clearance expenses for utility companies and their customers. A survey conducted in Pennsylvania, showed high approval by residents for the removal of large trees that interfered with utility lines (Flowers and Gerhold 2000) and replacement with smaller-growing trees that had been trialed in Pennsylvania landscapes (Gerhold 1985, 1999a, 1999b, 2000).

In 2000, the Virginia, Municipal Tree Restoration Program (MTRP) was started. It is a partnership representing a state agency (Virginia Department of Forestry), educational institutions [Virginia Tech's Hampton Roads Agricultural Research and Extension Center (HRAREC) and Community Design Assistance Center; Blue Ridge Community College], electric utility companies (Allegheny Energy, Appalachian Power, Dominion Virginia Power, Rappahannock Electric Cooperative), a nonprofit organization (Scenic Virginia), and interested municipalities (including Abingdon, Arlington, Chesapeake, Danville, Luray, Waynesboro, and Winchester).

Initially patterned after an MTRP started in Pennsylvania in 1987 (Gerhold 1999c), the major goals of Virginia's MTRP are

- To increase the general public's awareness of potential tree/utility conflicts.

- To increase recognition of tree/utility problems by municipal tree managers.

- To increase removal of utility-unfriendly trees by municipalities.

- To identify utility-appropriate trees by research and field trials.

- To increase availability of utility-appropriate tree species in the nursery trade.

- To increase awareness of potential tree/utility conflicts in new plantings by developers, city planners, and site plan reviewers.

To help achieve these goals, MTRP members decided that a series of utility line arboreta should be developed across Virginia to trial and showcase utility-compatible trees.

\section{MATERIALS AND METHODS}

In fall 1994, a demonstration area designated as a utility line arboretum was started at Virginia Tech's HRAREC in Virginia Beach, Virginia (USDA Hardiness Zone 8a). The objective in establishing this arboretum was to evaluate and showcase small trees and large shrubs compatible with overhead utility lines. Surveys and literature and Web searches were conducted to identify desirable plant characteristics and to develop a list of trees for initial evaluation (Appleton et al.
1997). Development of the arboretum served as a student's independent study project in Virginia Tech's extendedcampus Master of Science in Horticulture program (Appleton and French 2003).

To provide overhead lines for height reference, Dominion Virginia Power (then Virginia Power) erected three poles and two multi-line spans of uncharged electric lines totaling $91 \mathrm{~m}$ $(300 \mathrm{ft})$ at heights averaging $7.6 \mathrm{~m}(25 \mathrm{ft})$ and $9.1 \mathrm{~m} \mathrm{(30 \textrm {ft } )}$ above the ground. The first row of trees was established directly under the lines, with plants installed on $4.5 \mathrm{~m}(15 \mathrm{ft})$ centers (total of 20 plants per row). Additional rows were then added parallel to the initial row, $4.5 \mathrm{~m}(15 \mathrm{ft})$ apart.

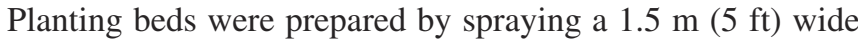
band with glyphosate (Roundup; Monsanto, St. Louis, MO) to kill existing vegetation. Plants were installed following Virginia Tech tree and shrub planting guidelines (Appleton and French 1996). Entire rows were then mulched with 5 to $7.5 \mathrm{~cm}$ (2 to 3 in) of wood chips (recycled from local utility line clearance) to suppress additional vegetative growth. Details of items and costs associated with developing a similar utility line arboretum are listed in Table 1.

All small trees [averaging 1.2 to $2.4 \mathrm{~m} \mathrm{(4} \mathrm{to} 8 \mathrm{ft})$ tall] and large shrubs [averaging 0.6 to $0.9 \mathrm{~m}$ ( 2 to $3 \mathrm{ft}$ ) tall] planted in 1994 and 1995 were obtained from local retail and wholesale nurseries. Due to financial constraints, only one tree or shrub per species was planted to maximize the number of plants that could be purchased and evaluated.

Included in the initial planting were two trees with mature heights over $15.2 \mathrm{~m}(50 \mathrm{ft})$, one centered under each of the two line spans. These two trees, a red maple (Acer rubrum) and a London planetree (Platanus $\times$ acerifolia), were included to emphasize the size of trees that should not be planted in or near utility easements. For this study, Dominion Virginia Power's usual easement distances (generally 3 m [10 $\mathrm{ft}$ ] in all directions around distribution lines) were used because there are no set easement dimensions uniformly used by utility companies across the United States. Each of these trees was labeled with a sign explaining that it is an inappropriately tall tree used for height reference.

In 1996, 14 trees deemed appropriate for mid-Atlantic conditions were selected and planted from the J. Frank Schmidt $\&$ Son Company (Boring, OR) line of Utilitrees ${ }^{\mathrm{TM}}$ (Appleton et al. 1997). The trees were a donation from the nursery in support of the utility line arboretum concept. In subsequent years, additional trees and shrubs have been added, most being less common plants obtained from mail-order nurseries (Forest Farms, Williams, OR; Klehm's Song Sparrow Perennial Farm, Avalon, WI; Rare Find Nursery, Jackson, NJ; Roslyn Nursery, Dix Hills, NY).

Tree height has been recorded on a yearly basis, and trees that have exceeded height expectations or that failed to survive or appeared inappropriate (excess litter, suckering, pest 


\section{Table 1. Steps, components, estimated basic costs, and potential funding sources for development of utility line} arboreta.

\begin{abstract}
Steps and components
Obtain a site where planting, maintenance, and pruning for height restriction are under your control, if possible (many street tree situations mean someone else controls tree maintenance, which may be counter to your objectives). Possible locations: city and county parks, school and university grounds, botanical gardens and arboreta, community centers, etc. A utility line arboretum can also be developed along a street, but be aware of energized overhead utility lines that may limit your activities.
\end{abstract}

Install one or more spans of lines.

Lay out planting design. Leave 6.1 to $7.6 \mathrm{~m}$ (20 to $25 \mathrm{ft}$ ) between each tree.

Prepare planting sites either as individual planting holes or entire planting rows.

Purchase trees, 1.2 to $2.4 \mathrm{~m}$ ( 4 to $8 \mathrm{ft}$ ) if available. Work with local nurseries to obtain acclimated trees.

Install trees.

Mulch trees.

Install informational signage (project name, cooperators, funding sources, etc.).

Tag individual trees with common and Latin names.

Seek funds for tree maintenance, removal, and replacement.

problems, growth rate) have been removed. As of August 2005, there were 170 trees and shrub species and cultivars planted in the HRAREC Utility Line Arboretum. An additional 45 species and cultivars are being grown to planting size at the HRAREC container nursery facility. Each arboretum plant is labeled with a sign bearing both Latin and common names, and a sign listing all plants in the row was placed at the start of each row. A large sign in the middle of the arboretum bears both the arboretum's name and a list of all financial supporters.

Funding for plant purchases and maintenance for the HRAREC Utility Line Arboretum has thus far been provided by the Virginia Agricultural Council, the Virginia Nursery and Landscape Association, and the Virginia Urban and Community Forestry Assistance Grant program. Similar possible funding sources exist in most states. J. Frank Schmidt \& Sons Company Nursery continues to donate any trees requested if shipping costs are paid. Such tree donations can serve as a match for grants that require monetary or in-kind matches.

In 2004, a utility line arboretum similar in design to the HRAREC Utility Line Arboretum was started in Veteran's
Estimated basic costs and potential funding sources or sponsors

$\$ 0$, or fill in your cost if land must be purchased, leased, etc.

$\$ 0$. Work with your local utility so that it provides this free or as a grant match.

\$Minimal (tape measure, flags).

$\$ 0$ for soil preparation. Work with site owner or sponsor for donated preparation.

$\$ 50-\$ 100$ for herbicide (and sprayer) to kill existing vegetation.

Largest overall cost of project; average of $\$ 50-\$ 100$ per tree (wholesale). Consult the directory or website of your state nursery association for in-state availability. Ask for donations as a grant match.

$\$ 0$. Use city employees and equipment, or students, Master Gardeners, or other volunteers.

$\$ 0$. Recycle line-clearance chips or similar material. Ask commercial tree removal and line-clearance companies to dump on site.

$\$ 0-\$ 300$. Ask for a donation from your city park department, a local technical school, etc.

$\$ 1$ to $\$ 5$ per tree, depending on tagging method.

See suggested sources in text.

Park in Abingdon, Virginia (USDA Hardiness Zone 6b), and another one is currently (2005) under development on the Virginia Tech campus in Blacksburg, Virginia (USDA Hardiness Zone 6a). In the future the two Virginia Tech utility line arboreta will become not only single tree demonstration sites but also, similar to the tree selection research program in Pennsylvania (Gerhold 1985), sites for replicated species plantings to obtain more accurate information about tree adaptability in multiple Virginia climatic zones.

The HRAREC Utility Line Arboretum is a good model to follow in areas where no overhead utility lines already exist, or where uncharged lines are desired so that pruning and other demonstrations or activities can be safely conducted. It was decided, however, that other types of utility line arboreta were needed, and to date two additional models have been developed. One involves using existing charged overhead distribution lines along frequently traveled streets. Existing trees that have overgrown the lines and require frequent lineclearance pruning, or that have been determined to be hazard trees, are removed and replaced with trees compatible with overhead utility lines. The first utility line arboretum of this type was started in 2002 in Abingdon, Virginia (USDA Har- 
Table 2. A comparison of advantages and disadvantages of three utility arboreta models.

\begin{tabular}{|c|c|c|}
\hline $\begin{array}{l}\text { Type of utility line } \\
\text { arboretum }\end{array}$ & Advantages & Disadvantages \\
\hline $\begin{array}{l}\text { City street with } \\
\text { existing overhead } \\
\text { lines }\end{array}$ & $\begin{array}{l}\text { - No pole and line installation required. } \\
\text { - High visibility for public, commercial, and municipal } \\
\text { education. } \\
\text { - Cooperation with numerous city entities may be } \\
\text { necessary. } \\
\text { - Trees serve multiple functions (aesthetics, cooling, } \\
\text { erosion control, noise abatement, glare reduction, } \\
\text { stormwater retention, etc.). } \\
\text { - Tree and maintenance costs may be a city } \\
\text { responsibility. }\end{array}$ & $\begin{array}{l}\text { - No control over line location. } \\
\text { - Space may be more restrictive relative to species } \\
\text { selection. } \\
\text { - Cooperation with numerous city entities may be } \\
\text { necessary. } \\
\text { - Public may be displeased with removal of hazard trees. } \\
\text { - May lose control of tree pruning to the utility } \\
\text { company. } \\
\text { - Volunteer activities may be more constrained or } \\
\text { regulated. }\end{array}$ \\
\hline $\begin{array}{l}\text { Demonstration site } \\
\text { with existing } \\
\text { overhead lines }\end{array}$ & $\begin{array}{l}\text { - No pole or line installation required. } \\
\text { - More flexibility regarding additional uses of site. } \\
\text { - Species selection may be more flexible. } \\
\text { - May lose control of tree pruning to the utility } \\
\text { company. }\end{array}$ & $\begin{array}{l}\text { - No control over line location. } \\
\text { - Generally all tree purchase, installation, and } \\
\text { maintenance costs are the site's responsibility. } \\
\text { - Visibility for public, commercial, and municipal } \\
\text { education may be limited. }\end{array}$ \\
\hline $\begin{array}{l}\text { Demonstration site } \\
\text { without existing } \\
\text { overhead lines }\end{array}$ & $\begin{array}{l}\text { - Control over line location, site development, and tree } \\
\text { pruning. } \\
\text { - Lines installed are not energized. } \\
\text { - More flexibility regarding additional uses of site. } \\
\text { - Greatest flexibility relative to species. } \\
\text { - Total control over tree pruning. }\end{array}$ & $\begin{array}{l}\text { - Requires pole and line installation. } \\
\text { - Generally all tree purchase, installation, and } \\
\text { maintenance costs are the site's responsibility. } \\
\text { - Visibility for public, commercial, and municipal } \\
\text { education may be limited. }\end{array}$ \\
\hline
\end{tabular}

diness Zone 6b). Thirty hazardous trees (determination made by the arborist jointly employed by Appalachian Power and Abingdon) along Abingdon's two main streets were removed and 80 new trees were planted. Designated utility line arboreta of this type are being developed in several other Virginia cities.

The third utility line arboretum model involves using existing overhead lines where no trees are currently growing. The first of this type of arboretum was started in 2002 in Arlington, Virginia (USDA Hardiness Zone 7a), as part of the W\&OD Railroad Regional Park. Rather than being planted under distribution lines, the trees in this utility line arboretum are planted under transmission lines, some of which are relatively low, thereby still providing an overhead reference and reminder of the existence of a utility corridor. A second of this type of utility line arboretum was started in 2004 at the Chesapeake Arboretum in Chesapeake, Virginia (USDA Hardiness Zone 8a), using distribution lines that parallel a major road bordering the arboretum. A summary of the advantages and disadvantages of our three utility line arboreta models is provided in Table 2.

All Virginia utility line arboreta are designated as such with MTRP signs. The MTRP logo (a stylized tree that looks like an arrow pointing up toward overhead utility lines) and slogan ("Look Up Virginia") are prominent on each sign. The MTRP goals are also printed on the signs (Figure 1).

HRAREC's Utility Line Arboretum is used not only to evaluate and showcase utility-compatible trees, but also for numerous other activities. The Horticulture Program of Tidewater Community College (Chesapeake, Virginia) uses it for woody plant identification courses. Virginia Cooperative Extension uses it for Master Gardener and Tree Steward woody plant identification and pruning instruction. The Arborist Training Program of the Norfolk Botanical Garden (Norfolk, Virginia) uses it for tree planting and pruning practicum for its students (Parsons and Scott 2004).

As mentioned earlier, two inappropriately tall trees were planted in the HRAREC Utility Line Arboretum for height

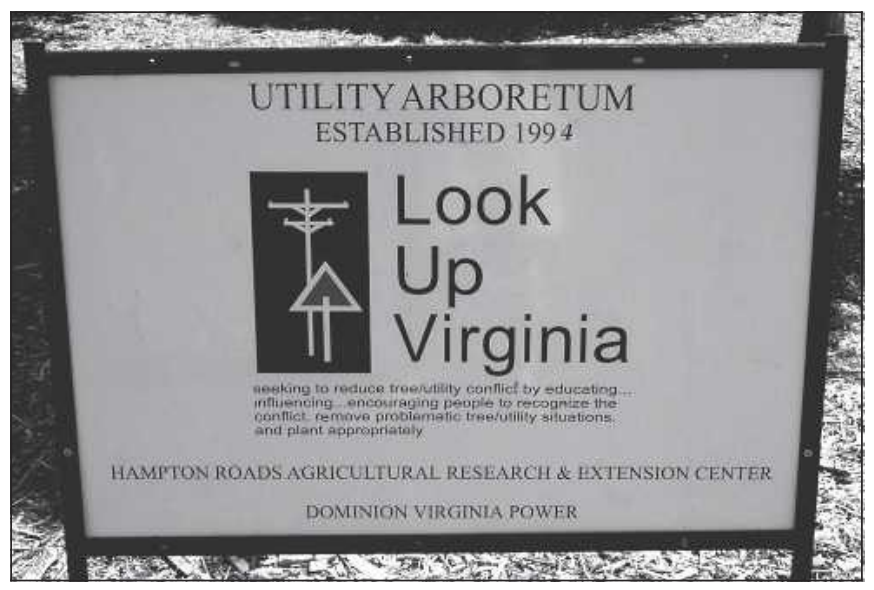

Figure 1. The Municipal Tree Restoration Program (MTRP) sign used to identify utility line arboreta in Virginia. 
reference and to highlight trees incorrectly sited under overhead distribution lines. Every few years, when these trees overgrow the lines, Dominion Virginia Power and Asplundh Tree Expert Company, a line-clearance contractor, use the trees for demonstrations of correct utility line-clearance pruning during HRAREC industry field days.

\section{DISCUSSION}

Small trees and overhead utility lines can coexist in aesthetic and nonhazardous combinations if size and maintenance requirements are considered when the trees are selected. The use of appropriately sized trees will significantly reduce power interruptions and outages, as well as line-clearance and tree removal costs. Regional tree selection trials, such as those being conducted in Pennsylvania and Virginia, greatly aid in the selection of trees compatible with overhead utility lines. Utility line arboreta, for the purpose of evaluating, showcasing, and promoting appropriate trees, can be established for a relatively low cost if grants are sought and partnerships established.

Although one of the three utility line arboreta presented here should be appropriate for almost any site on which development of a utility line arboretum might be desired, for development of any future utility line arboreta, several changes in our initial process are recommended. Where trees will be lined out in rows as in the HRAREC Utility Line Arboretum, spacing plants on $4.5 \mathrm{~m}(15 \mathrm{ft})$ centers within rows was often too close for full tree canopy spread develop and for maintenance activities around the trees. It is recommended that trees be spaced a minimum of 6.1 to $7.6 \mathrm{~m}$ (20 to $25 \mathrm{ft}$ ) apart within rows, with trees offset from each other in adjacent parallel rows. Adjacent rows should also be spaced a minimum of $6.1 \mathrm{~m}$ to $7.6 \mathrm{~m}$ (20 to $25 \mathrm{ft}$ ) apart.

In addition, height is not the only dimension that needs to be considered when trees are selected for utility line arboreta. Many trees planted under overhead utility lines will be planted in strips between roads and sidewalks, as in the utility line arboreta along the two main streets in Abingdon, VA. Trees with broad spreads, such as flowering dogwood (Cornus florida) and Kwanzan cherry (Prunus serrulata), though their height may be appropriate, may be too wide for the location. In addition, because lower limbs will need to be removed (crown raising) to provide adequate clearance for pedestrians and vehicles, the appearance of many small trees may be ruined and their health stressed. Where horizontal landscape space is limited, small trees with more upright, columnar, or fastigiated forms are preferable. This selection criterion is being considered for all future trees to be trialed at Virginia utility line arboreta.

Utility line arboreta, like any designed landscape feature, require far more than funding for initial development. A commitment must be made to ongoing maintenance and removal and replacement of trees as needed. As noted for the
HRAREC Utility Line Arboretum, many additional uses can be made for this type of landscape feature, often lending assistance with funding and maintenance. Multiple uses of utility line arboreta also increase community involvement and exposure.

Information about the tree-overhead utility line conflict, conflict resolution options, and recommended trees and shrubs for easement plantings (USDA Hardiness Zones 6 to 8) are detailed in a Virginia Cooperative Extension publication (Appleton et al. 2002) that is posted on and printable from the Internet (www.ext.vt.edu/pubs/trees/430-029/430029.html). With a grant from the National Urban and Community Forestry Assistance Council (NUCFAC), the above publication was developed in template form, as well as templates of a PowerPoint presentation and poster on utility line arboreta and utility line-compatible trees. In 2004 these materials were distributed to all state urban forestry coordinators in the United States for regional customization and use and were posted to the website of Urban Forestry South Expo (www.urbanforestrysouth.org/Resources/Collections/ Collection.2004-10-22.0537/view).

Additional information about this utility line arboreta project has been published in industry trade magazines (Appleton 2003, 2004; Appleton et al. 2003). Virginia MTRP recently launched a website (www.utilityfriendlytrees.org) where the above materials, and more, are posted.

\section{CONCLUSIONS}

The development of utility line arboreta is important to demonstrate to the public, to landscape designers and architects, and to municipalities that a wide variety of small trees and large shrubs, with either mature heights not exceeding the height of overhead utility lines or with growth rates that can help extend line-clearance cycles, are readily available in commercial nursery production in the United States. Many of the species we are evaluating and recommending, or similar species, are available worldwide, making the development of utility line arboreta feasible and appropriate wherever this tree-infrastructure conflict exists.

Acknowledgments. This work has been supported by grants from the Virginia Department of Forestry, the Virginia Agricultural Council, and the National Urban and Community Forestry Assistance Council and by trees from J. Frank Schmidt \& Son Company.

\section{LITERATURE CITED}

ANSI. 1997. National Electric Safety Code. ANSI C2. American National Standards Institute, New York, NY.

Appleton, B. 2003. Utility room. American Nurseryman 197(3):41-45.

2004. Trees: A threat to homeland security? Tree Care Industry 15(6):46-51. 
Appleton, B.L., and S.C. French. 1996. Tree and Shrub Planting Guidelines. Publication 430-295 of Virginia Cooperative Extension. Blacksburg, VA. 2 pp.

- 2003. Virginia Polytechnic Institute and State University's extended campus Master of Science degree program in horticulture. HortTechnology 13(2):388-392.

Appleton, B., S. French, and B. Johnson-Asnicar. 2003. Trees for problem landscape sites: Trees and shrubs for overhead utility easements. Groundwork (Jan):20-23.

Appleton, B.L., S.C. French, and B.M. Johnson-Asnicar. 2002. Trees for Problem Landscape Sites: Trees and Shrubs for Overhead Utility Easements. Publication 430029 of Virginia Cooperative Extension. Blacksburg, VA. 4 pp.

- B.M., Touchette, S.C. French, and A.X. Niemiera. 1997. Developing a utility line arboretum. Journal of Arboriculture 23(6):219-223.

Department of Energy. 2003. Hurricane Isabel: A summary of energy impacts and OEA's response. www.ea.doe.gov/ pdfs/isabelreport_10-7-03.pdf (accessed 5/2/2005).

Dominion Virginia Power. 2003. Dominion Virginia Power begins restoring power; hurricane Isabel worst storm in company history. www.dom.com/news/elec2003/pr0919.jsp (accessed 5/2/2005).

Flowers, D.E., and H.D. Gerhold. 2000. Replacement of trees under utility wires impacts attitudes and community tree programs. Journal of Arboriculture 26(6):309-318.

Gerhold, H.D. 1985. Performance testing of street tree cultivars: A model project. Journal of Arboriculture 11(9): 263-271.

- 1999a. Tree lilac cultivars tested as street trees: Initial results. Journal of Arboriculture 25(4):185-188.

- 1999b. Serviceberry cultivars tested as street trees: Initial results. Journal of Arboriculture 25(4):189-192.

- 1999c. Municipal trees restored through partnerships. Pennsylvania Forests 90(1):15-17.

- 2000. Crabapple cultivars tested as street trees: Second report. Journal of Arboriculture 26(1):48-54.

Guggenmoos, S. 2003. Effects of tree mortality on power line security. Journal of Arboriculture 29(4):181-196.

Merullo, V.D., and M.J. Valentine. 1992. Arboriculture and the Law. International Society of Arboriculture, Champaign, IL, pp. 61-68.

Parsons, A., and M.K. Scott. 2004. Program helps at-risk youth find jobs in tree care. Tree Care Industry 15(9): 42-44, 46.

Urban Forestry South Expo. 2005. Trees and Utilities Collection (Appleton NUCFAC 2004). www.urbanforestrysouth.org/ Resources/Collections/ Collection.2004-10-22.0537/view (accessed 5/3/2005).

U.S.-Canada Power System Outage Task Force. 2004. Final report on the 14 August 2003 blackout in the United
States and Canada: Causes and recommendations. U.S.Canada Power System Outage Task Force, Washington, DC.

Bonnie L. Appleton

Professor of Horticulture

Hampton Roads Agricultural Research and Extension

Center

Virginia Polytechnic Institute and State University

1444 Diamond Springs Road

Virginia Beach, VA 23455, U.S.

bapple@vt.edu

Résume. Aux États-Unis, un conflit significatif existe entre les lignes électriques et les arbres inappropriés de grandes dimensions qui sont plantés sous ou près du droit de passage de ces lignes. Un objectif majeur du programme municipal de restauration des arbres en Virginie est l'aménagement d'arboretums d'arbres et de lignes électriques en plusieurs endroits de l'état afin d'évaluer, de montrer et de promouvoir l'utilisation d'espèces d'arbres compatibles. Trois modèles différents d'arboretums de lignes électriques ont été développés et qui peuvent être reproduits n'importe où dans le monde afin de gérer cet important conflit d'infrastructures. Une liste par étapes logiques d'éléments et de sources potentielles de fonds pour développer ce type d'arboretum est fournie tout comme une comparaison des avantages et des inconvénients de chacun des trois modèles d'arboretums de lignes électriques et d'arbres qui sont décrits.

Zusammenfassung. In den Vereinigten Staaten gibt es einen deutlichen Konflikt zwischen Hochspannungsleitungen und unangemessenen großen Bäumen, die in der Nähe oder darunter gepflanzt sind. Ein Hauptziel des Baumerhaltungsprogramms von Virginia ist die Etablierung von Arboreta unterhalb von Hochspannungsleitungen an vielen Standorten, um die geeigneten Bäume zu bewerten und zu demonstrieren. 3 verschiedene Baumgartenmodelle wurden entwickelt und können nun beliebig transportiert werden, um diesem wichtigen Infrastrukturkonflikt zu begegnen. Hier wird eine Schritt-für-Schritt-Anleitung für Überlegungen und Möglichkeiten der Mittelbeschaffung geliefert und ein Vergleich der Vorund Nachteile der 3 beschriebenen Baumgartenmodelle.

Resumen. En los Estados Unidos, existe un conflicto significativo entre las líneas áreas de servicios y los árboles plantados de forma inapropiada en o cerca de los derechos de vía. Uno de los principales objetivos del Proyecto Municipal de Restauración de Árboles de Virginia (MTRH, por sus siglas en inglés) es el establecimiento de un arboreto de líneas de servicios en múltiples localidades del estado como una forma de evaluar, mostrar y promover la compatibilidad entre los árboles y las líneas aéreas. Se han desarrollado tres diferentes modelos que pueden ser replicados en cualquier parte, internacionalmente, con el fin de trabajar con esta importante infraestructura de conflicto. Se proporciona una lista de consideraciones y fuentes de fondos potenciales para el desarrollo de arboretos, como también una comparación de las ventajas y desventajas de los tres modelos descritos. 